Palaeoentomology 002 (4): 312-315

https://www.mapress.com/j/pe/

Copyright (C) 2019 Magnolia Press

\section{Editorial}

ISSN 2624-2826 (print edition)

PALAEOENTOMOLOGY

ISSN 2624-2834 (online edition)

https://doi.org/10.11646/palaeoentomology.2.4.2

http://zoobank.org/urn:1sid:zoobank.org:pub:AFEE2E7B-CEB8-43E2-BDF6-425325EAD1A3

\title{
Deeply mourn the memory of my supervisor, Professor Peiji Chen
}

\section{GANG LI}

State Key Loboratory of Palaeobiology and Stratigraphy, Center for Excellence in Life and Palaeoenvironment, Nanjing Institute of Geology and Palaeontology, Chinese Academy of Sciences, Nanjing 210008, China. E-mail: gangli@nigpas.ac.cn

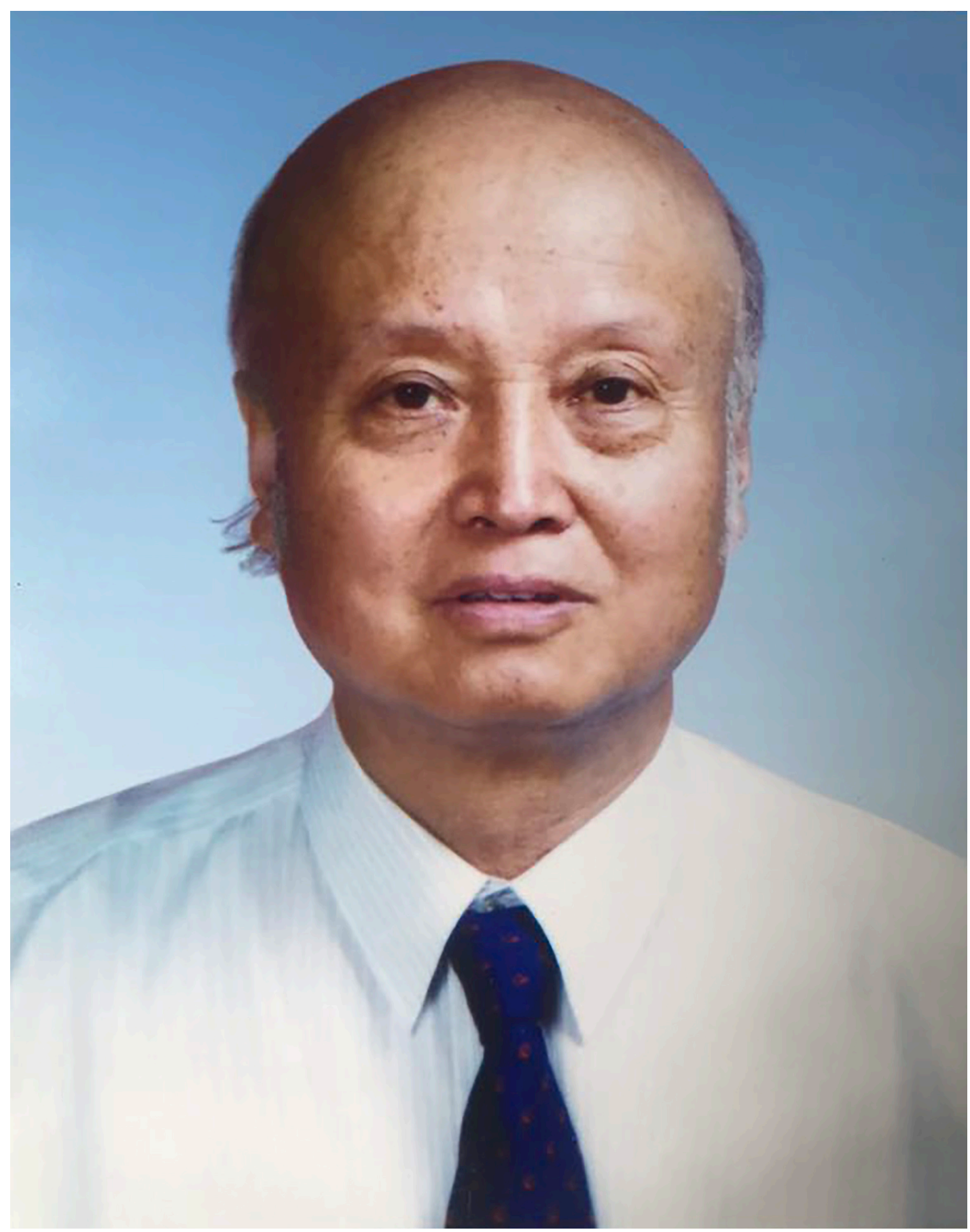

Prof. Peiji Chen

16.03.1936-09.07.2019 
Professor Peiji Chen, an internationally renowned paleontologist, passed away in Xi' an at 4:30 a.m. on July 9, 2019, at the age of 83 .

Prof. Peiji Chen was born on March 16, 1936 in Xi'an City, Shaanxi Province, northwestern China. At the beginning of his education, he studied in Qishan East Street Primary School. Then he transferred to the First Provincial Experimental Primary School in Xi'an. In 1949, he passed the entrance examination, and entered the First Provincial Middle School in Xi'an, which is now the Xi'an Middle School. In 1955, he passed the national unified university entrance examination, and began to study palaeontology and stratigraphy in the Department of Geology, Beijing University. He graduated from Beijing University in 1960, and became employed at the Institute of Palaeontology, Chinese Academy of Sciences, i.e., now the Nanjing Institute of Geology and Palaeontology, Chinese Academy of Sciences, to begin his academic professional career on the study of fossil clam shrimps (Chen \& Shen, 1981, 1985; Shen \& Chen, 1984; Chen, 1994; Chen et al., 2007; Chen, 2012; Li et al., 2014), tadpole shrimps (Chen, 1985), the branchiopod extinct order Kazacharthra (Chen \& Zhou, 1985; Chen et al., 1996) and non-marine Mesozoic stratigraphy (Chen \& Chang, 1994; Chen, 2003a, b; Li et al., 2004; Chen et al., 2005; Wan et al., 2007). It has been 65 years since he began to study geology in Beijing University. He was an internship researcher, an Assistant Professor, an Associate Professor and a Full Professor. He also once served as an Adjunct Professor in the Department of Geology, Beijing University and Northwestern University.

Prof. Peiji Chen has been engaged in the fields of palaeontology, stratigraphy, palaeogeography, palaeobiogeography, palaeoenvironment and plate tectonic movement over the years. He published more than 160 academic papers, monographs and edited memoirs. He was rigorous in his study, and had a sharp mind; many of his research results won national, provincial and ministerial awards. Among them, the "Fossil Conchostraca of China" (Zhang et al., 1976), co-authored with his supervisor Prof. Wentang Zhang and junior fellow apprentice Prof. Yanbin Shen, completed the foundation work on taxonomy of fossil clam shrimps from China. It won the second prize of the National Natural Science Progress, this achievement has been widely used and recognized by the international academic circles. "Biostratigraphy and geological evolution in Tarim Basin" (Zhou \& Chen, 1990), compiled in co-operation with Prof. Zhiyi Zhou, won the first prize of the Natural Science and Technology Progress of Chinese Academy of Sciences. "An outline of palaeogeography during the Jurassic and Cretaceous periods of China - with a discussion on the origin of the Yangtze river" (Chen, 1979) won the fourth prize of the Jiangsu Provincial Science and Technology Progress. He had long been committed to the study of the Jehol Biota, and his achievements in the study of the Jehol Biota and its stratigraphy have won the first prize for scientific and technological progress in Jiangsu Province (Chen, 1999a; Chen \& Jin, 1999). He had an original opinion on many important scientific problems, such as the evolution and migration of the Jehol Biota (Chen, 1988a, 1999b, Chang et al., 2001, 2003), the large horizontal displacement age of the Tanlu fault (Chen, 1988b, c), the collision between Tarim-South China block and North China block (Chen $\&$ Norling, 1994), and the uplift of coastal mountains of southeastern China and the desertification and salinization of lakes in Central China during the Late Cretaceous (Chen, 1997).

Prof. Chen, a researcher who had been active in the international Cretaceous academic circle, was invited to study the palaeontology of fossil clam shrimps in the United Kingdom, Japan, Australia and Harvard University in the United States (Chen \& Hudson, 1991; Chen et al., 1993; Chen, 1996; Chen \& Suzuki, 1998). Since his first visit to the Uppsala University in Sweden in 1981 to attend the Seventh International Colloquium on the mid-Cretaceous Events, he was constantly active in the forefront of domestic and international Cretaceous research, known by his colleagues as "Cretaceous Chen". He went abroad 36 times in 23 years, visiting 24 countries and regions. In cooperation with the Ministry of Petroleum Industry, he organized two large-scale national meetings on the Cretaceous of South and North China, respectively. He co-operated with Dr. N. Mateer and coled the IGCP 245 project of "Non-marine Cretaceous Correlation" (Mateer \& Chen, 1988). In addition, he acted as the Chinese regional coordinator of IGCP 350 "Cretaceous Environmental Change in East and South Asia" and IGCP 434 "Land-Ocean Interactions of Carbon Cycle and Bio-Diversity Change during the Cretaceous in Asia". In 1987, he organized the First International Symposium of IGCP 245 in Urumqi, Xinjiang Uygur Autonomous Region of China. In 1996, during the $30^{\text {th }}$ International Geological Congress, he organized the Fourth International Symposium of IGCP 350 in Beijing. In 1994, as a guest editor, he compiled a special issue of "Cretaceous research in China" in the international academic journal "Cretaceous Research", which made the Chinese Cretaceous research team one of the most advanced in the world. From 1997 to 2000, he presided over the research project "The Jehol Biota", which was supported by a major fund of the Chinese Academy of Sciences and a key fund of the National Natural Science Foundation of China. In co-operation with Zhiming Dong and Shuonan Zhen, he published a paper in "Nature" in 1998 "An exceptionally well-preserved theropod dinosaur from the Yixian Formation of China" (Chen et al., 1998). The taxonomic revision of "Sinosauropteryx" 
was conducted there. This clarifies that Sinosauropteryx is not a bird, nor a direct ancestor of birds, but a theropod dinosaur with a body covered by primitive feathers. This article has been widely cited and reported by scientific journals and news media in home land and abroad, and was awarded the "Classical Citation Award" by ISI in Beijing on 25 September 2000. This is one of the 213 most influential papers, selected from 200,000 accepted Chinese papers published by SCI and SSCI journals in the 18 years from 1981 to 1998 . It was also the only selected paper in the field of Geoscience and Biology in China at that time.

Prof. Peiji Chen actively participated in academic organizations, served as a council member and the Deputy Secretary General of the Chinese Palaeontological Association, a member of the Chinese National Association of Science and Technology, the Vice Chairman of the Mesozoic Branch of the Chinese National Stratigraphic Committee and the leader of Chinese Cretaceous Working Group. He had long-served as editorial board members of academic journals, such as "Science in China", "Chinese Science Bulletin", "Chinese Palaeontology", "Journal of Stratigraphy", and the international journal "Cretaceous Research". He also actively supervised many students to provide talent reserve for our palaeontology and stratigraphy.

\section{References}

Chang, M.M., Chen, P.J., Wang, Y.Q. \& Wang, Y. (2001) The Jehol Biota. Shanghai Scientific \& Technical Publisher, Shanghai, 150 pp. [In Chinese].

Chang, M.M., Chen, P.J., Wang, Y.Q. \& Wang, Y. (2003) The Jehol Biota. Shanghai Scientific \& Technical Publisher, Shanghai, 208 pp.

Chen, P.J. (1979) An outline of palaeogeography during the Jurassic and Cretaceous periods of China-with a discussion on the origin of the Yangtze river. Acta Scientiarum Naturalium Universitatis Pekinensis, 3, 90-109 [In Chinese with English abstract].

Chen, P.J. (1985) Jurassic Triops from South China-with a discussion on the distribution of Notostraca. Acta Palaeontologica Sinica, 24, 285-292 [In Chinese with English abstract].

Chen, P.J. (1988a) Distribution and migration of Jehol fauna with reference to non-marine Jurassic/Cretaceous boundary in China. Acta Palaoentologica Sinica, 27, 659-683 [In Chinese with English summary].

Chen, P.J. (1988b) Lower Cretaceous volcano-sedimentary rocks of East China with reference to the age of horizontal displacement of the Tancheng-Lujiang fault. In: Mateer, N.J. \& Chen, P.J. (Eds.) Aspects of Non-marine Cretaceous Geology, p. 1-14.
Chen, P.J. (1988c) the age and pattern of the large horizontal displacement of the Tanlu Fault. Chinese Science Bulletin, 33, 289-293 [In Chinese].

Chen, P.J. (1994) Cretaceous conchostracan faunas of China. Cretaceous Research, 15, 259-269. https://doi.org/10.1006/cres.1994.1016

Chen, P.J. (1996) Lower Cretaceous conchostracans of SW Japan. Bulletin of Kitakyushu Museum Natural History, 15, 305321.

Chen, P.J. (1997) Coastal mountains of SE China, desertization and saliniferous lakes of Central China during the Upper Cretaceous. Journal of Stratigraphy, 21, 203-213 [In Chinese with English abstract].

Chen, P.J. (1999a) Distribution and spread of the Jehol Biota. Palaeoworld, 11, 1-6 [In Chinese with English abstract].

Chen, P.J. (1999b) Fossil conchostracans from the Yixian Formation of western Liaoning, China. Palaeoworld, 11, 114-130 [In Chinese with English abstract].

Chen, P.J. (2003a) Jurassic biostratigraphy of China. In: Zhang, W.T., Chen, P.J. \& Palmer, A.R. (Eds.), Biostratigraphy of China. Science Press, Beijing, p. 423-464.

Chen, P.J. (2003b) Cretaceous biostratigraphy of China. In: Zhang, W.T., Chen, P.J. \& Palmer, A.R. (Eds.), Biostratigraphy of China. Science Press, Beijing, p. 465-532.

Chen, P.J. (2012) Cretaceous conchostracan biostratigraphy of China. Journal of Stratigraphy, 36, 300-313.

Chen, P. \& Chang, Z.L. (1994) Nonmarine Cretaceous stratigraphy of eastern China. Cretaceous Research, 15, 245-257. https://doi.org/10.1006/cres.1994.1015

Chen, P.J. \& Hudson, J.D. (1991) The conchostracan fauna of the Great Estuarine Group, Middle Jurassic, Scotland. Palaeontology, 34, 515-545.

Chen, P.J. \& Jin, F. (Eds.) (1999) Jehol Biota. Palaeoworld, 11, $1-342$.

Chen, P.J. \& Norling, E. (1994) Tectonic wedge in Tibet and cracking of Tarim-South China Block. Chinese Science Bulletin, 39, 1512-1515 [In Chinese].

Chen, P.J. \& Shen, Y.B. (1981) Paleogene conchostracan faunas of China. Geological Society of America, Special Paper, 187, 193-197. https://doi.org/10.1130/SPE187-p193

Chen, P.J. \& Shen, Y.B. (1985) An introduction to fossil Conchostraca. Science Press, Beijing, 241 pp., 26 pls. [In Chinese].

Chen, P.J. \& Suzuki, S. (1998) A new species of Nemestheria (Crustacea, Conchostraca) from the Aioi Group (Cretaceous) of Okayama, Japan. Paleontological Research, 2, 25-29.

Chen, P.J. \& Zhou, H.Z. (1985) A preliminary study on fossil Kazacharthra from Turpan Basin. Chinese Science Bulletin, 30, 950-954.

Chen, P.J., Dong, Z.M. \& Zhen, S.N. (1998) An exceptionally well preserved theropod dinosaur from the Yixian Formation of China. Nature, 391, 147-152.

https://doi.org/10.1038/34356 
Chen, P.J., Li, G. \& Batten, D.J. (2007) Evolution, migration and radiation of late Mesozoic conchostracans in East Asia. Geological Journal, 42, 391-413. https://doi.org/10.1002/gj.1064

Chen, P.J., McKenzie, K.G. \& Zhou, H.Z. (1996). A further research into Late Triassic Kazacharthra fauna from Xinjiang Uygur Autonomous Region, NW China. Acta Palaeontologica Sinica, 35, 272-302.

Chen, P.J., Naito, G., Kameya, A. \& Okamoto, K. (1993) Late Cretaceous conchostracans from Kiwado of Yamaguchi Prefecture, Japan. Bulletin of Yamaguchi Museum, 19, 1-11.

Chen, P.J., Wang, Q.F., Zhang, H.C., Cao, M.Z., Li, W.B., Wu, S.Q. \& Shen, Y.B. (2005) Jianshangou bed of the Yixian Formation in west Liaoning, China. Science in China Series D Earth Sciences, 48, 298-312.

https://doi.org/10.1360/04yd0038

Li, G., Chen, P.J., Wan, X.Q., Jiang, J.H., Liu, J.C., Yin, D.S., Yan, W. (2004) Stratotype of the basal boundary of the Nenjiangian stage, Cretaceous. Journal of Stratigraphy, 28, 297-299 [In Chinese with English abstract].
Li, G., Wang, S.E., Chen, P.J. \& Willems, H. (2014) Morphological study of the type species of Fengninggrapta (Crustacea: Spinicaudata) from the Xiguayuan Formation of northern Hebei Province, northern China. Acta Palaeologica Sinica, $53,527-532$.

Mateer, N.J. \& Chen, P.J. (1988) Aspects of non-marine Cretaceous geology. China Ocean Press, Beijing, 304 pp.

Shen, Y.B. \& Chen, P.J. (1984) Late Middle Jurassic conchostracans from the Tuchengzi Formation of W Liaoning, NE China. Bulletin of the Nanjing Institute of Geology and Palaeontology, Academia Sinica, 9, 309-326 [in Chinese with English abstract].

Wan, X.Q., Chen, P.J. \& Wei, M.J. (2007) The Cretaceous system in China. Acta Geologica Sinica, 81, 957-983. https://doi.org/10.1111/j.1755-6724.2007.tb01019.x

Zhang, W.T., Chen, P.J. \& Shen, Y.B. (1976) Fossil Conchostraca of China. Science Press, Beijing, 325 pp. [In Chinese].

Zhou, Z.Y. \& Chen, P.J. (1992) Biostratigraphy and geological evolution of Tarim. Science Press, Beijing, 366 pp. [In Chinese]. 